\title{
Redescription of Platygyndes Roewer 1943, a false Gonyleptidae, (Arachnida, Opiliones, Cosmetidae)
}

\author{
Ricardo Pinto-Da-Rocha', Marcos Ryotaro Hara² \\ I Departamento de Zoologia, Instituto de Biociências, Universidade de São Paulo, Caixa Postal 11461, São \\ Paulo, SP, Brazil, 05422-970 2 Escola de Artes, Ciências e Humanidades, Universidade de São Paulo, Av. \\ Arlindo Bettio no 1000, Ermelino Matarazzo, São Paulo, SP, Brazil, 03828-000
}

Corresponding author: Ricardo Pinto-Da-Rocha (ricrocha@usp.br)

Academic editor: D. Logunov | Received 16 August 2011 | Accepted 19 October 2011 | Published 1 November 2011

Citation: Pinto-Da-Rocha P, Hara MR (2011) Redescription of Platygyndes Roewer 1943, a false Gonyleptidae, (Arachnida, Opiliones, Cosmetidae). ZooKeys 143: 1-12. doi: 10.3897/zookeys.143.1916

\begin{abstract}
Praelibitia Roewer, 1956 and its type species, Praelibitia titicaca Roewer, 1956, are respectively synonymized with Platygyndes Roewer, 1943 and its type species Platygyndes titicaca Roewer, 1943, and furthermore the genus is transferred from the Gonyleptidae to the Cosmetidae. On the basis of domed and unarmed ocularium, increased number of granules on scutal areas, unarmed dorsal scutum and general body shape, Platygyndes seems to be closely related to Moselabius Roewer, 1956 and Caracarana Roewer, 1956. External morphological characters that are useful to revealing relationships among cosmetid genera are discussed.
\end{abstract}

\section{Keywords}

Andes; Neotropical fauna; systematics; taxonomy; harvestmen

\section{Introduction}

Cosmetidae is a highly diverse Laniatores family with over 700 described species distributed from southern USA to southern Patagonia, including the Greater and Lesser Antilles (Kury 2003; Pinto-da-Rocha and Kury 2007; Hallan 2011). The family is easily diagnosed by the pedipalps, which cover the frontal part of the chelicerae: pedipalpal femur is strongly compressed laterally, pedipalpal tibia is spoon-shaped and 
unarmed or weakly armed (Kury and Pinto-da-Rocha 2007). Despite the impressive richness (the third most speciose family of Opiliones), only a few attempts, such as Ferreira and Kury (2010), have been made to review its classification using alternative characters compared to those used by Rower. Some recent works, e.g. Townsend et al. (2010), are only an extension of Roewer's system, enriched by images of male genitalia, of which characters were not used in the generic classification. Other rich Neotropic families, such as the Sclerosomatidae and the Gonyleptidae, have received much more attention in the last decade. Several subfamilies of the Gonyleptidae have been revised (Pinto-da-Rocha 2002; Yamaguti and Pinto-da-Rocha 2009; DaSilva and Gnaspini 2009; DaSilva and Pinto-da-Rocha 2010; Pinto-da-Rocha and Bragagnolo 2010), as well as the South American Sclerosomatidae (Tourinho and Kury 2001, 2003; Tourinho 2003, 2004a, 2004b). Yet, the Cosmetidae remains the biggest challenge for the laniatorid systematics of the $21^{\text {st }}$ century.

This paper is a first step in tackling this challenge, and it is based on our current investigations relevant to a revision of the Gonyleptidae. Here we redescribe Platygyndes titicaca Roewer, 1943, so far considered in the Gonyleptidae (Pachylinae), and propose its transfer to the Cosmetidae. Indeed, this species possesses some features unusual for the cosmetids: viz., (i) pedipalpal femur is moderately flattened and not projected dorsally; (ii) pedipalpal tibia is moderately flattened laterally; and (iii) evident scutal grooves I-V present. It is possible that these features would have misled Roewer who placed Platygyndes in the Gonyleptidae. Finally, based on its external morphology, P. titicaca Roewer, 1943 is found to be a senior synonym of Praelibitia titicaca Roewer, 1956; it is another example of the same species described by Roewer twice, with its male and female placed in different families.

\section{Methods}

The nomenclature follows Acosta et al. (2007), with some modifications adapted specifically to the studied group. Carapace refers to the part of dorsal scutum that covers the prosoma. The scutal area $\mathrm{V}$ is referred to as posterior margin of dorsal scutum. SMF stands for the depository of Naturmuseum Senckenberg, Frankfurt am Main, Germany (curator: P. Jäger). In synonymic lists, we adopted the following abbreviations: cat=catalogue; juv=juvenile(s); rdes=redescription. Only the different characteristics regarding the male were mentioned in the female redescription. The illustrations of the external morphology were made under a stereomicroscope using camera lucida with the material immersed in $70 \%$ ethanol. The genitalia were prepared according to Pinto-da-Rocha (1997) and illustrated using a compound microscope with camera lucida. Measurements are in millimeters.

We have also examined the type materials of ten laniatorid species from the genera which may be phylogenetically close to Platygyndes: Eulibitia annulipes Roewer, 1912 (male holotype; SMF 447); E. maculata Roewer, 1912 (male holotype; SMF 471); E. sexpunctata Roewer, 1919 (male holotype; SMF 473); Caracarana inermis Roewer, 1956 (male holo- 
type; SMF 9730); Metalibitia adunca (Roewer, 1927) (male holotype; SMF 143/9); Metalibitia borelli (Roewer, 1925) (male paratype; SMF 121/3); Metalibitia maculata (Roewer, 1914) (1 male and 1 female paratypes; SMF 1060); Metalibitia tibialis (Roewer, 1925) (2 males; SMF 122/4); Moselabius albipunctatus Roewer, 1956 (6 males and 14 females; SMF 1394/297); Syncynorta longipes Roewer, 1947 (female holotype; SMF 5865/207).

\section{Systematics}

\section{Cosmetidae, Cosmetinae}

\section{Platygyndes Roewer, 1943, new familial and subfamilial assignment} http://species-id.net/wiki/Platygyndes

Platygyndes Roewer, 1943: 16; Soares and Soares 1954: 291 (rdes, cat). Type species Platygyndes titicaca Roewer, 1943, by monotypy.

Praelibitia Roewer, 1956: 442 (type species Praelibitia titicaca Roewer, 1956, by original designation). new synonymy.

Diagnosis. Platygyndes is a Cosmetidae having the domed and narrow ocularium, instead of the depressed medially and widened one, which is common in eastern and several Andean species. Moreover, this genus possesses the well-marked scutal grooves I-V; the moderately flattened, not dorsally projected pedipalpal femur; and the moderated, laterally flattened pedipalpal tibia which strongly contrast with the typical type observed in the family (strongly flattened and spoon-shaped). On the basis of unarmed domed ocularium and dorsal scutum, the genus seems to be more closely related with Moselabius Roewer, 1956 and Caracarana Roewer, 1956. Moselabius known only after a female can be distinguished from Platygyndes by larger and sparser tubercles on the dorsal scutum and a paramedian pair of the enlarged tubercles on free tergites I-III and thickened tibiae IV. Caracarana differs from Platygyndes by the incrassate femur IV, the pedipalpal tibia with a ventral projection, the thickened and basally constricted tibia IV, the thickened and curved metatarsus IV and the long tarsal process.

\section{Platygyndes titicaca Roewer, 1943}

http://species-id.net/wiki/Platygyndes_titicaca

Figs $1-3$

Platygyndes titicaca Roewer, 1943: 16, pl. 1, fig 1; Soares and Soares 1954: 291 (cat); Acosta 1996: 222 (cat); Kury 2003: 187 (cat) (Peru [“Titicaca Seeufer"], male holotype, SMF RII 7736/112, examined).

Praelibitia titicaca Roewer, 1956: 442; Kury 2003: 82 (cat) (Peru ["bei Chucuito am Titicaca See, 3900 m”], female holotype, 11.III.53, H.W. Koepcke leg., SMF RII 

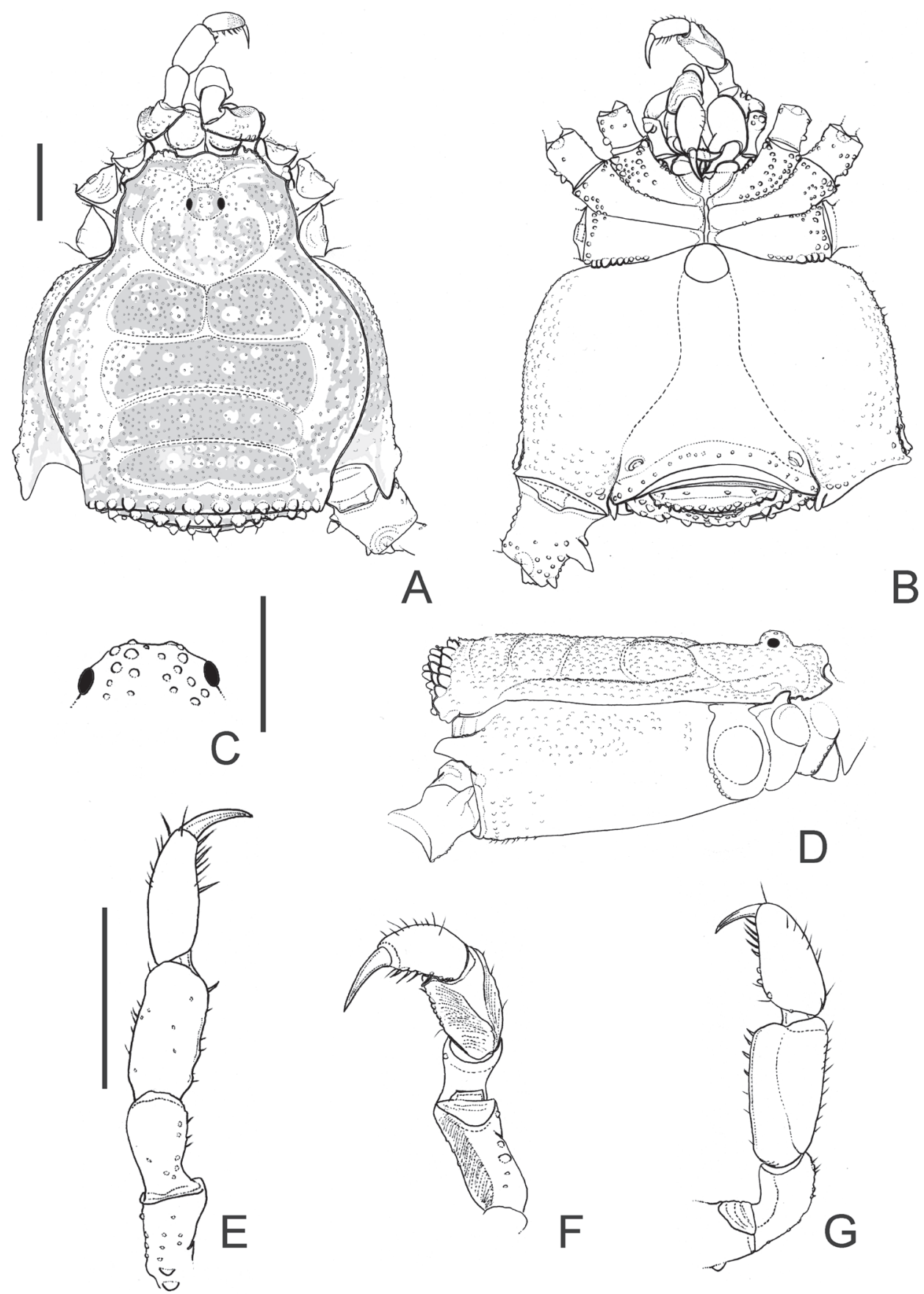

A
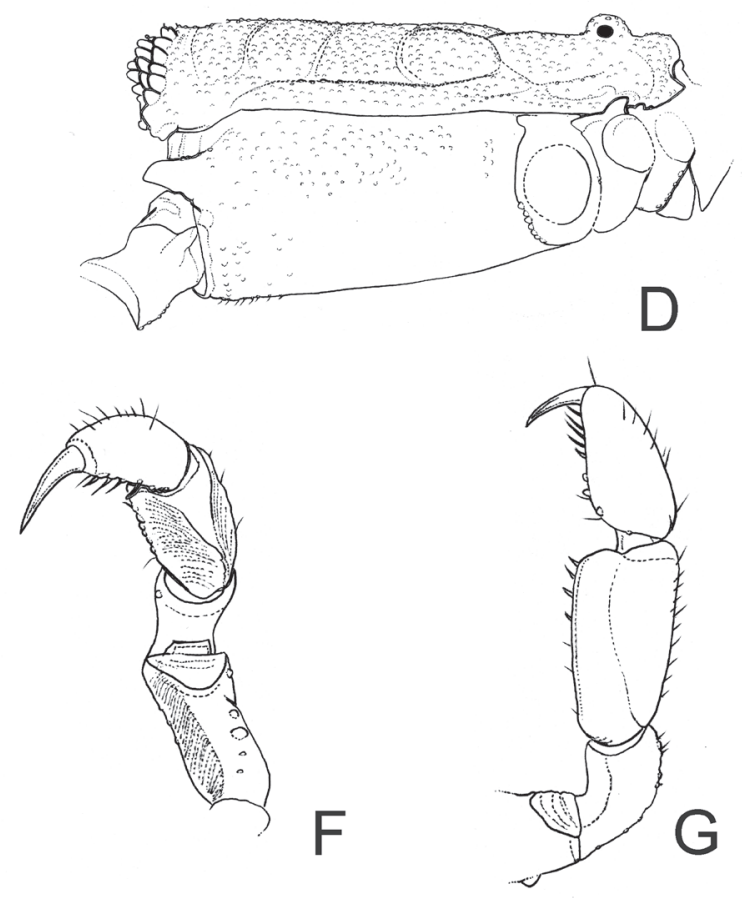

Figure I. Platygyndes titicaca Roewer. Male (holotype): A habitus, dorsal view B ditto, ventral view $\mathbf{D}$ ditto, right lateral view $\mathbf{C}$ ocularium, anterior view $\mathbf{E}$ left pedipalp, dorsal view $\mathbf{F}$ ditto, ventral view G retrolateral view A, B, D at the same scale E-G at the same scale. Scale bar $1 \mathrm{~mm}$ except for $\mathbf{C}$ which is $0.5 \mathrm{~mm}$. 
9726; idem, 1 female $\& 4$ juv. paratypes [however only 1 female $\& 2$ juv. in vial], SMF 9727, examined). NEW SYNONYMY

\section{Type locality. Peru: Puno (shores of Titicaca Lake).}

Note. The label of type material of Platygyndes titicaca has no data beyond "Titicaca-Seeufer" (shores of Titicaca Lake), although Roewer (1943) clearly states Peru as the type locality of this species. Kury (2003) argued that the department of Puno (the sole department close to Titicaca Lake in the Peruvian side) seems to be a more precise type locality of the species; he also indicated that the correct country could be Bolivia. We agree with the latter suggestion of Kury (2003).

Material examined. PERU. Puno: without further data on locality ("Titicaca Seeufer" [shores of Titicaca Lake]), male holotype of Platygyndes titicaca, without more precise locality, name of collectors or date, SMF RII 7736/112; Chucuito ("bei Chucuito am Titicaca See" [near Chucuito at Titicaca Lake], $3900 \mathrm{~m}$ ), female holotype of Praelibitia titicaca, 11.III.53, H.W. Koepcke leg., SMF RII 9726; idem, 1 female \& 2 juv. paratypes of Praelibitia titicaca, SMF RII 9727.

Description. Male (holotype; SMF RII 7736/112). Measurements: carapace maximum length 1.8 ; carapace maximum width 2.1 ; dorsal scutum maximum length 4.6; dorsal scutum maximum width 4.1; femur IV length 3.1; legs I-IV length 6.8; 10.9; 9.9; 13.9. Dorsum (Fig. 1A, C, D): dorsal scutum shape type gamma (Kury et al. 2007), flattened, granulated, widest at scutal area II. Paracheliceral projections not conspicuous, rounded. Anterior margin of dorsal scutum with three enlarged and fused together tubercles on each corner. Ocularium domed (without median depression), narrow (around a fifth of carapace width), densely minute-tuberculate. Lateral margin of dorsal scutum with less granules than scutal areas. Scutal grooves I-V clearly visible, delimiting four scutal areas. Scutal areas I-IV unarmed, I divided by a longitudinal groove. Posterior margin of dorsal scutum with a row of 14 conical, enlarged tubercles. Free tergites I-III granulated, each with a row of 11, 9 and 10 conical, enlarged minute tubercles, respectively. Anal opercle with anterior row of 6 and a group of 16 tubercles. Venter (Fig. 1B): coxae I-IV granulated, distal half of coxae I, distal posterior of coxae II-III with enlarged tubercles. Posterior margin fused to the stigmatic area slightly concave. Mesotergal sternites each with a row of minute tubercles. Anal opercle with one anterior and one posterior row of tubercles. Chelicera (Fig. 1A): not swollen. Bulla dorsally covered by tubercles. Movable and fixed fingers each with 4 tooth. Pedipalps (Fig. 1E-G): trochanter with three ventral tubercles. Femur moderately flattened, not projected dorsally, with five dorsal wide tubercles, four ventral tubercles (subdistal one largest). Tibia spatulate, moderately projected ventrally, tibia-tarsus with lateral setae. Legs (Figs 1A, 2, 3A-E): coxa I with one prolateral apophysis, this blunt, large and one retrolateral bifid apophysis; II with one prolateral apophysis, this large, obliterating ozopore and curved frontwards and one retrolateral apophysis, this fused with prolateral apophysis of coxa III; III with one prolateral, one retrolateral apophyses; IV anteriorly with a shoulder-like shape in dorsal view, reaching scutal groove IV, densely granulated, one prolateral apical apophysis with capitate apex directed backwards, one 

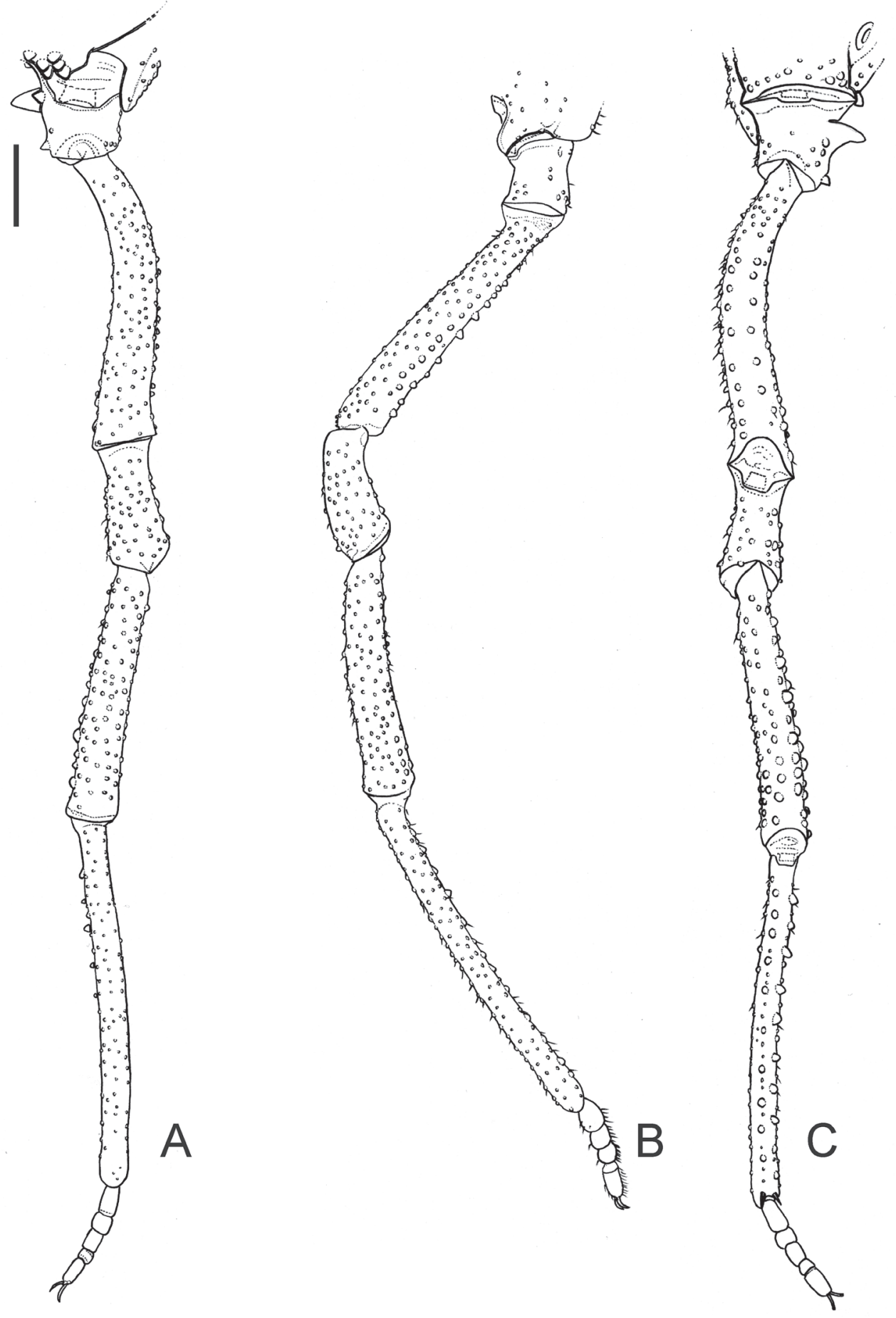

Figure 2. Platygyndes titicaca Roewer. Male (holotype): Right leg IV A dorsal view B, prolateral view C ventral view. Scale bar: $1 \mathrm{~mm}$. 
retrolateral apical large tubercle. Trochanters I-IV granulate; I-II with two retrolateral enlarged tubercles; III with one retrolateral enlarged tubercle; IV retrolaterally with a median apophysis, this conical, its length half of the podomere width, one submedian and one apical enlarged tubercles. Femora and tibiae I-IV tuberculate and roughly arranged in longitudinal rows. Femora III-IV slightly curved, with two ventral rows of tubercles slightly increasing in size apicad, more conspicuous in femur III. Tibia-metatarsus IV ventrally with enlarged tubercles. Tarsi I with globose and short tarsomeres; III-IV with smooth claws, short tarsal process (around a fifth of tarsal claw length). Tarsal formula: 5(3), 5-6(3), 5, 5. Penis (Fig. 3F, G): glans elongated, covering most of stylus dorsally. Stylus with inflated apex and thin projections in distal margin dorsoventrally. Ventral plate rectangular, thick, with two pairs of curved distal setae, one pair of straight submedian setae, two pairs of basal setae (the basalmost one shortest), two pairs of very small setae (placed between the main groups of setae on the left or between submedian and basal group of setae on the right).

Female (holotype of Praelibitia titicaca; SMF RII 9726). Measurements: carapace maximum length 1.8.; carapace maximum width 2.0; dorsal scutum maximum length 5.2; dorsal scutum maximum width 4.3; femur IV length 3.1; leg I-IV length 7.2; 10.9; 9.4; 12.9. Dorsum: dorsal scutum shape type alpha, wider at scutal groove II, narrowed at scutal area III. Posterior margin of dorsal scutum and free tergites I-III each with a row of 13, 9, 11 and 10 conical, enlarged tubercles, respectively. Legs: coxa IV only visible apically (in dorsal view), reaching groove III, with prolateral apical apophysis shorter than male. Trochanters I-IV without enlarged tubercles or apophyses. Femur and tibia-metatarsus IV ventrally with tubercles of similar size. Tarsal formula: 5(3), 5(3), 5, 5.

Remarks. Platygyndes titicaca possesses the moderately flattened pedipalpal femora which are not projected dorsally and the moderated, laterally flattened pedipalpal tibia compared to the spoon-shaped (flattened and concave) in the majority of cosmetids; besides, it has the unusually well-marked scutal grooves I-V. These unusual features might have led Roewer to assign it to the Gonyleptidae, Pachylinae. It is worth mentioning that the male genitalia of $P$. titicaca are undoubtedly of the cosmetid groundplan, not of that of the Gonyleptidae. We have examined the Andean material deposited in the SMF and realized that Praelibitia titicaca described from a female was also collected close to the type locality of the monotypic Platygyndes. Considering the sexual dimorphism in cosmetids, the general body shape, ocularium and pedipalpal shape, dorsal scutum ornamentation and the remaining colour pattern, we have conclude that both names are synonyms. Thus the same species was classified by Roewer in different families, indicating once more that the Roewerian system of Opiliones is hardly reliable.

\section{Discussion}

Due to poor taxonomic characterization of the genera included in Cosmetidae, this family is among the least understood Neotropical Laniatores. Most genera are still diagnosed 

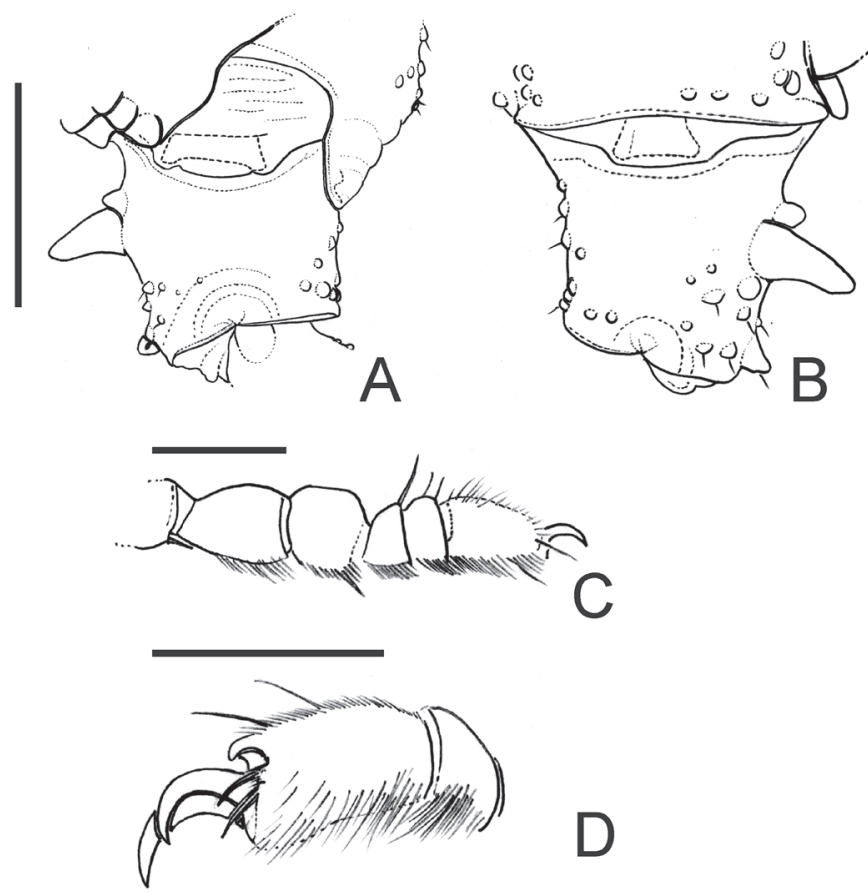

D
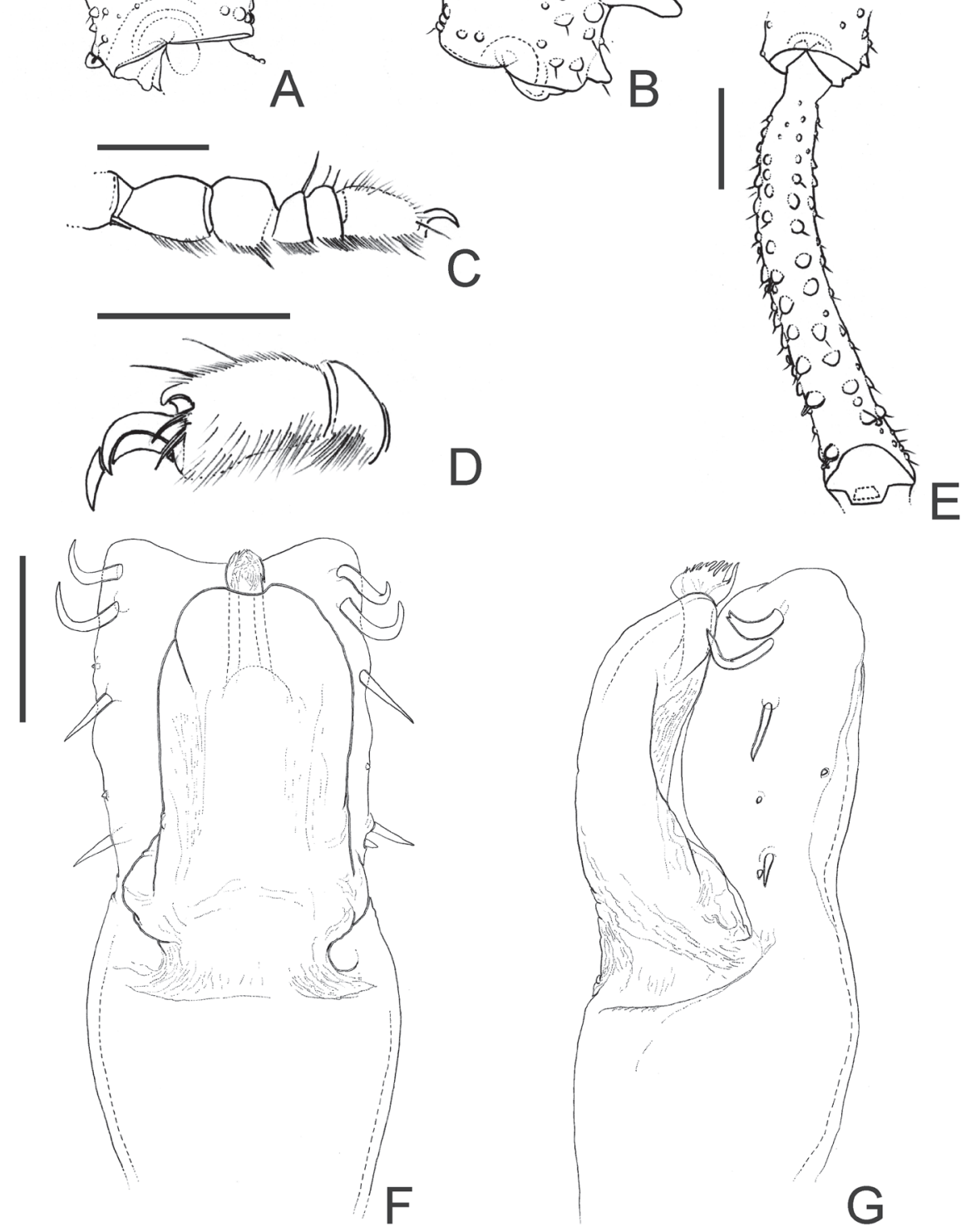

Figure 3. Platygyndes titicaca Roewer. Male (holotype): A right trochanter IV, dorsal view B ditto, ventral view $\mathbf{C}$ right tarsomeres I, retrolateral view $\mathbf{D}$ distalmost right tarsomere IV, prolateral view $\mathbf{E}$ right femur III, ventral view $\mathbf{F}$ penis, dorsal view $\mathbf{G}$ ditto, right lateral view $\mathbf{A}, \mathbf{B}$ at the same scale $\mathbf{F}-\mathbf{G}$ at the same scale. Scale bars A-E $1 \mathrm{~mm} \mathbf{F}, \mathbf{G} 0.1 \mathrm{~mm}$. 
by the Roewerian combination of armature on dorsal scutum and number of tarsal segments (e.g., Townsend et al. 2010). The Roewerian system relied on a limited set of characters and therefore highlighted predominantly the differences among species/specimens and resulted in many artificial groupings and monotypic genera. In the 1950s, certain attempts to resolve this situation were undertaken by the authors (e.g., Mello-Leitâo 1945, Soares 1943, Soares and Soares 1954) who began to take into account an intraspecific variation. In the Cosmetidae, for instance, Goodnight and Goodnight (1953) proposed synonymies for many genera, arguing that the observed differences were due to an intraspecific variation. Such tendency to synonymize the opilionid taxa described by Roewer had lasted until the end of the XX century, although in a more argumentative way.

Recently, Kury et al. (2007) advocated in using characters of the dorsal scutum. In Platygyndes, the shape of dorsal scutum is similar to the gamma-type: viz., the scutum convexity is much wider and displaced posteriorly, and there is a well-marked anterior constriction (as in Metalibitia) (see Table 1). However, the posterior constriction is wellmarked as well, differing from the original definition and being more similar to the alphatype (see Kury et al. 2007). Townsend et al. (2010) also reported on difficulties in classifying the alpha or gamma types. Having examined the female of Platygyndes titicaca, we can confirm that its dorsal scutum shape is clearly of the alpha-type. These data suggest that the shape of dorsal scutum may vary due to sexual dimorphism and such intraspecific variation should be considered while classifying its shape. Thus, we are of the opinion that the alpha-type should also include those dorsal scuta which present a well-marked posterior constriction and the strikingly widened part at rear. A practical option would be just merging the alpha- and gamma-types in a single category. Another structure that seems to be useful in delimitating genera is the male coxae IV: viz., its length (reaching the grooves III, IV, or the posterior margin of dorsal scutum), its visible extension in dorsal view (hidden or not under the dorsal scutum), its shape (parallel or apically divergent) and its apical armature. Additionally, the dorsal and ventral armature of tubercles on pedipalpal femora and the shape of pedipalpal tibia are also useful for a generic delimitation.

We have also found the ocularium to be very informative, although overlooked by many authors. Having examined the cosmetids from Andes and the eastern part of South America, we have confirmed the existence of at least two very distinct types of the ocularium: (i) the widened and medially depressed one, as in Cynorta (Kury et al. 2007, fig. 1), a condition which is indeed typical for the majority of cosmetids (Kury and Pinto-da-Rocha 2007; Ferreira and Kury 2010); and (ii) the narrow and domed one, as in Platygyndes (see Fig. 1A) and Caracarana. On the basis of the similarity both of the body shape and of the narrow ocularium, we consider Metalibitia, Eulibitia, Moselabius and Syncynorta as likely to be closely related to Platygyndes (Table 1); yet those genera possess the depressed ocularium. Furthermore, the pedipalp considered to date as a very conservative character of the family seems to be also useful for phylogenetic assessments. Platygyndes stands out as a cosmetid genus with moderate modifications of its pedipalps: viz., of femora and tibia, which are moderately flattened instead of strongly flattened laterally, and the typical spoon-shaped tibia are poorly-marked (this is why Roewer should have assigned this genus in the Gonyleptidae). Reasoning from the fact that cosmetid juveniles possess cylindrical pedipalps 
Table I. Comparison of the genera of Cosmetidae with narrow ocularium. Body shape according to Kury et al. (2007). ? = refers to unknown male.

\begin{tabular}{|c|c|c|c|c|c|c|}
\hline Genera & $\begin{array}{l}\text { Body } \\
\text { shape }\end{array}$ & Male coxa IV & $\begin{array}{l}\text { Ocularium } \\
\text { shape }\end{array}$ & Body dorsal armature & $\begin{array}{l}\text { Dorsal } \\
\text { pedipalpal } \\
\text { tibia shape }\end{array}$ & $\begin{array}{l}\text { Dimorphic } \\
\text { chelicera }\end{array}$ \\
\hline Platygyndes & $\begin{array}{l}\gamma \text { (male), } \\
\alpha \text { (female) }\end{array}$ & $\begin{array}{l}\text { Entirely visible } \\
\text { in dorsal } \\
\text { view, reaching } \\
\text { groove IV }\end{array}$ & Domed & \begin{tabular}{|l|} 
Scutal areas unarmed; \\
posterior margin of dorsal \\
scutum and free tergites with \\
a row of conical, enlarged \\
tubercles
\end{tabular} & $\begin{array}{l}\text { Almost } \\
\text { rectangular }\end{array}$ & Absent \\
\hline Caracarana & $\alpha$ & $\begin{array}{l}\text { Entirely visible } \\
\text { in dorsal } \\
\text { view, reaching } \\
\text { groove III }\end{array}$ & Domed & \begin{tabular}{|l|} 
Scutal areas unarmed; \\
posterior margin of dorsal \\
scutum and free tergites with \\
a row of conical, enlarged \\
tubercles
\end{tabular} & $\begin{array}{l}\text { Much wider } \\
\text { at apex }\end{array}$ & Absent \\
\hline Eulibitia & $\alpha$ & $\begin{array}{l}\text { Visible only } \\
\text { apically in } \\
\text { dorsal view, } \\
\text { reaching } \\
\text { groove III } \\
\end{array}$ & \begin{tabular}{|l|} 
Depressed \\
medially
\end{tabular} & Entirely unarmed & $\begin{array}{l}\text { Much wider } \\
\text { at apex }\end{array}$ & Absent \\
\hline Metalibitia & $\gamma$ & $\begin{array}{l}\text { Visible only } \\
\text { apically in } \\
\text { dorsal view, } \\
\text { reaching } \\
\text { groove IV } \\
\end{array}$ & $\begin{array}{l}\text { Depressed } \\
\text { medially }\end{array}$ & $\begin{array}{l}\text { Scutal areas I-III unarmed or } \\
\text { with a pair of tubercles; IV } \\
\text { with two large tubercles }\end{array}$ & $\begin{array}{l}\text { Almost } \\
\text { rectangular }\end{array}$ & Absent \\
\hline Moselabius & $\alpha$ & $\begin{array}{l}\text { Visible only } \\
\text { apically in } \\
\text { dorsal view; } \\
\text { reaching } \\
\text { groove IV } \\
\end{array}$ & $\begin{array}{l}\text { Depressed } \\
\text { medially }\end{array}$ & $\begin{array}{l}\text { Posterior margin of dorsal } \\
\text { scutum and free tergites with } \\
\text { a pair of enlarged tubercles }\end{array}$ & $?$ & Present \\
\hline Syncynorta & $\alpha$ & $?$ & Domed & $\begin{array}{l}\text { Scutal areas I-IV and posterior } \\
\text { margin of dorsal scutum with } \\
\text { a pair of enlarged tubercles; } \\
\text { free tergites with row of large } \\
\text { tubercles }\end{array}$ & Rectangular & $?$ \\
\hline
\end{tabular}

before gaining it of the typical shape in adults, it is safe to conclude that Platygyndes may belong to a basal cosmetid lineage in which the spoon-shaped tibia are fully developed.

The aforementioned characters are likely to be useful in revealing phylogenetic relationships within the speciose Cosmetidae. A high number of the described species, as well as their poor descriptions and illustrations, and past failures in resolving the taxonomic status of confusing species and genera definitely present a serious challenge (even more serious than that posed by the Gonyleptidae 20 years ago). Although being time and resource consuming, the most reliable option to tackle this challenger seems to be a re-examination of available type material and a further search for reliable characters in order to better resolve phylogenetic relationships within the family. 


\section{Acknowledgments}

We wish to thank Dr Peter Jäger and Julia Altmann from the Senckenberg Museum for their kind hospitality and for giving access to collection facilities. We are also deeply indebted to Drs Adriano Brilhante Kury (Brazil) and Nobuo Tsurusaki (Japan) for their critical comments helping to improve the ms. Dr Dmitri Logunov (UK) edited the English of the final draft. MRH and RPR received grant from the Fundação de Amparo à Pesquisa do Estado de São Paulo (FAPESP), 2009/03111-2 and 2008/06604-7, respectively.

\section{References}

Acosta LE (1996) Die Typus-Exemplare der von Carl-Friedrich Roewer beschriebenen Pachylinae (Arachnida: Opiliones: Gonyleptidae). Senckenbergiana biologica 76 (1/2): 209-225.

Acosta LE, Pérez-Gonzalez A, Tourinho AL (2007) Chapter 15: Methods and Techniques of Study: Methods for taxonomic study. In: Machado G, Pinto-da-Rocha R, Giribet G (Eds) Harvestmen, the biology of Opiliones. Harvard University Press, Cambridge, Massachusetts and London, 494-505.

DaSilva MB, Gnaspini P (2009) A systematic revision of Goniosomatinae (Arachnida: Opiliones: Gonyleptidae), with a cladistic analysis and biogeographical notes. Invertebrate Systematics 23 (6): 530-624. doi: 10.1071/IS09022.

DaSilva MB, Pinto-da-Rocha R (2010) Systematic review and cladistic analysis of the Hernandariinae (Opiliones: Gonyleptidae). Zoologia 27 (4): 577-642. doi: 10.1590/S198446702010000400010.

Ferreira CP, Kury AB (2010) A review of Roquettea, with description of three new Brazilian species and notes on Gryne (Opiliones, Cosmetidae, Discosomaticinae). Zoological Science 27: 697-708. doi: 10.2108/zsj.27.697.

Goodnight CJ, Goodnight ML (1953) The Opilionid fauna of Chiapas, Mexico, and adjacent areas (Arachnoidea, Opiliones). American Museum Novitates 1610: 1-81.

Hallan J (2011) Arachnida catalog. Synopsis of the described Arachnida of the World. http://insects. tamu.edu/research/collection/hallan/Acari/Family/Opiliones1.htm [accessed August 2011]

Kury AB (2003) Annotated catalogue of the Laniatores of the New World (Arachnida, Opiliones). Revista Ibérica de Aracnología vol. esp. monográfico no 1:5-337.

Kury AB, Pinto-da-Rocha R (2007) Cosmetidae. In: Machado G, Pinto-da-Rocha R, Giribet G (Eds) Harvestmen, the biology of Opiliones. Harvard University Press, Cambridge, Massachusetts and London, 182-185.

Kury AB, O Villarreal M, Sampaio C (2007) Redescription of the type species of Cynorta (Arachnida, Opiliones, Cosmetidae). Journal of Arachnology 35 (2): 325-333. doi: 10.1636/H06-35.1 
Mello-Leitão CF de (1945) Considerações sobre o gênero Eusarcus Perty e descrição de quatro novos Laniatores. Anais da Academia Brasileira de Ciências 7 (2): 149-162.

Pinto-da-Rocha R (1997) Systematic review of the neotropical family Stygnidae (Opiliones, Laniatores, Gonyleptoidea). Arquivos de Zoologia, São Paulo 33 (4): 163-342.

Pinto-da-Rocha R (2002) Systematic review and cladistic analysis of the Caelopyginae (Opiliones: Gonyleptidae). Arquivos de Zoologia, São Paulo 36 (4): 357-464.

Pinto-da-Rocha R, Bragagnolo C (2010) Systematic revision and cladistic analysis of the Brazilian subfamily Sodreaninae (Opiliones: Gonyleptidae). Invertebrate Systematics 24: 509538. doi: 10.1071/IS10030.

Roewer CF (1943) Über Gonyleptiden. Weitere Weberknechte (Arachn., Opil.) XI. Senckenbergiana 26 (1-3): 12-68.

Roewer CF (1956) Arachnida arthrogastra aus Peru II. Senckenbergiana biologica 37 (5-6): 429-445.

Soares BAM (1943) Aracnídeos de Goiás coligidos pelo dr. Frederico Lane. Papéis Avulsos do Departamento de Zoologia do Estado de São Paulo 3 (13): 205-218.

Soares BAM, Soares HEM (1954) Monografia dos gêneros de opilióes neotrópicos III. Arquivos de Zoologia do Estado de São Paulo, São Paulo 8 (9): 225-302.

Tourinho AL (2003) On the dubious identity of Bastioides Mello-Leitão, 1931 (Eupnoi, Sclerosomatidae, Gagrellinae). Revista Ibérica de Aracnología 7: 241-245.

Tourinho AL (2004a) The third South American species of Pectenobunus Roewer, with a new synonym for the genus (Opiliones, Eupnoi, Sclerosomatidae, Gagrellinae). Zootaxa 405: 1-16.

Tourinho AL (2004b) A new genus of Gagrellinae from Brazil, with a comparative study of some of the Southermost tropical and subtropical South American species (Eupnoi, Sclerosomatidae, Gagrellinae). Revista Ibérica de Aracnología 9: 157-177.

Tourinho AL, Kury AB (2001) Notes on Holcobunus Roewer, 1910 (Arachnida, Opiliones, Sclerosomatidae). Boletim do Museu Nacional, n.s. Zoologia, Rio de Janeiro 461: 1-22.

Tourinho AL, Kury AB (2003) A review of Jussara, with descriptions of six new species (Arachnida, Opiliones, Sclerosomatidae) from Brazil. Tropical Zoology 16 (2): 209-275.

Townsend Jr VR, Víquez C, VanZandt PA, Proud DN (2010) Key to the Cosmetidae (Arachnida, Opiliones) of Central America, with notes on penis morphology and sexual dimorphisms. Zootaxa 2414: 1-26.

Yamaguti HY, Pinto-da-Rocha R (2009) Taxonomic review of Bourguyiinae, cladistic analysis, and a new hypothesis of biogeographic relationships of the Brazilian Atlantic Rainforest (Arachnida: Opiliones, Gonyleptidae). Zoological Journal of the Linnean Society 156: 319-362. doi: 10.1111/j.1096-3642.2008.00484.x 